\title{
THE COFFEE COMMODITY CHAIN IN THE WORLD-ECONOMY: ARRIGHI'S SYSTEMIC CYCLES AND BRAUDEL'S LAYERS OF ANALYSIS
}

\author{
John M. Talbot \\ Department of Sociology \\ University of the West Indies, Mona \\ john.talbot@uwimona.edu.jm
}

\begin{abstract}
This article presents a history of coffee in the modern world-economy, using an analytical framework synthesized from Arrighi's concept of systemic cycles of accumulation and Braudel's notion of three levels of economic analysis: material life, the market economy, and capitalism. It takes the commodity chain as the unit of analysis, and argues that this choice helps to illuminate the causal connections between Braudel's three layers. The method of incorporated comparison is used to compare restructurings of the coffee commodity chain with the restructurings of the larger world-economy during each of Arrighi's systemic cycles.
\end{abstract}

\section{INTRODUCTION}

In this paper, I use Arrighi's four "systemic cycles of accumulation" as a framework to describe and explain transformations of the world coffee economy, focusing on the use of coffee in everyday life and the global trade in coffee. ${ }^{1}$ I link these changes to the recurrent pattern that Arrighi identifies for each systemic cycle, moving through alternating periods of "material" and "financial" expansion. I attempt to explain how the changes in material life and the market economy were shaped by, and in turn helped to shape, the development of each systemic cycle of accumulation as a whole. I employ a variation of McMichael's (1990, 1992) method of incorporated comparison to compare changes in the structure of the coffee commodity chain with changes in the world-economy, because the former is a part of the latter. When a hegemonic power restructures the world-economy, it does so by restructuring the commodity chains that comprise it. However, each commodity chain also has its own logic and history, which condition its further evolution and render it either open, or resistant, to restructuring at particular historical conjunctures. Instances where the evolution of the commodity chain does not correspond exactly with the evolution of the world-economy may provide important clues about the dynamics

\footnotetext{
${ }^{1}$ Arrighi describes each systemic cycle as beginning in the financial expansion of the preceding cycle, running through the material expansion, and including the subsequent financial expansion. This yields a series of overlapping systemic cycles which is probably truer to the development of capitalism as the top layer of the system (1994: 214-15). For this analysis, I have dated the beginning of each cycle at the beginning of the material expansion to obtain a series of non-overlapping cycles, which makes it easier to deal with events in the two lower layers of the system.
} 


\section{JOURNAL OF WORLD-SYSTEMS RESEARCH}

underlying the evolution of each. The article concludes with some generalizations drawn from the analysis and some reflections on the theoretical framework.

\section{ANALYTICAL FRAMEWORK}

Giovanni Arrighi's The Long Twentieth Century (1994) stands as a masterpiece of world-systems analysis. Arrighi sets out to construct, as he puts it, a "genealogy of modern capitalism ... as a succession of systemic cycles of accumulation" (1994: 84). Arrighi's analysis shows how capitalism began in the system of northern Italian city-states in the fourteenth century and expanded to encompass the entire planet. The development and expansion of capitalism has been accomplished through a succession of systemic cycles: the Genoese, Dutch, British, and U.S. Each cycle begins as a new hegemonic power, with new organizational capabilities, leads an expansion and restructuring of the system. Each cycle has two phases: a material expansion followed by a financial expansion. The material expansion begins when the new hegemon embarks on a process of restructuring of both the world economy and the interstate system to serve its interests; however, these interests are always presented as, and to some extent perceived as, the general interests of the system as a whole. During the material expansion, capital is invested primarily in the expansion of production and trade in goods. But as the material expansion proceeds, it generates more profits than can be profitably re-invested in production and trade. As this happens, a growing share of capital is diverted into speculation and financial deals, inaugurating the financial expansion. This stimulates competition between states to attract the growing volume of mobile capital, causing increasing instability and chaos in the system. At the same time, other rising capitalist powers copy the organizational innovation of the hegemonic state, undercutting its power and ability to lead. The crisis that follows is eventually resolved by the rise of a new hegemonic power, offering a new organizational innovation that initiates a new expansion and restructuring of the system.

Arrighi draws heavily on Fernand Braudel's three-volume magnum opus, Civilization \& Capitalism $15^{\text {th }}-18^{\text {th }}$ Century $(1981 ; 1982 ; 1984)$. In this work, Braudel conceptualizes the totality of economic life as consisting of three intersecting layers, which he calls material life, the market economy, and capitalism. The bottom layer in this construction, material life, is described as the "infra-economy, the informal other half of economic activity, the world of self-sufficiency and barter of goods and services within a very small radius." (1981: 24) The middle layer of the market economy consists of all those activities which have traditionally been considered economic: exchanges between freely competing buyers and sellers in markets. The top layer, capitalism, in Braudel's memorable phrase, is "the zone of the anti-market, where the great predators roam and the law of the jungle operates." (1982: 230, quoted in Arrighi 1994: 10) However, Arrighi's analysis focuses primarily on this top layer of the three-tiered structure:

The notion of systemic cycle of accumulation, we have noted, derives directly from Braudel's notion of capitalism as the top layer of the hierarchy of the world of trade. Our analytical construct, therefore, focuses on that top layer and offers a limited view of what goes on in the middle layer of market economy and the bottom layer of material life. This is simultaneously the main strength and the main weakness of the construct. (24) 
As Arrighi notes, "we cannot do everything at once." (25) And he has done quite a lot, not only setting out a genealogy of capitalism, but also opening up a research program. For, as he notes:

The logic of the top layer is only relatively autonomous from the logics of the lower layers and can be fully understood only in relation to these other logics. ... [This] requires that we descend again to explore the lower layers of market economy and material life with the knowledge and questions brought back from the journey into the top layer which this book undertakes. (26)

In order to advance this research program, it is necessary to understand not only the distinctions between these three layers, but also the ways in which they are connected. Braudel never presents an extended, systematic discussion of these distinctions and connections; he interjects brief sketches of them throughout the three volumes of Civilization and Capitalism. We have to attempt to construct a systematic account from the sketches. He starts with the definition of material life quoted above, as the informal and subsistence economy. But his discussion in the first volume ranges much more broadly than this. Central chapters in this volume discuss food and eating habits, beverages and drinking habits, clothing styles, and the construction and decoration of housing. He concludes this section by saying that:

our investigation takes us at this point not simply into the realm of material 'things', but into a world of 'things and words' - ... languages with everything that man contributes or insinuates into them ... And those strange collections of commodities, symbols, illusions, fantasms and intellectual schemas that we call civilizations must also be invoked at this point. (1981: 333)

Rather than simple, informal, economic activity, then, what he is discussing here might better be labeled material civilization, which he seems to use as a synonym for material life. This includes all of the material objects of everyday life as well as the cultural meanings attached to them. He further clarifies at the beginning of the second volume:

Between 'material life' (in the sense of an extremely elementary economy) and 'economic life', the contact surface is not continuous, but takes the form of thousands of humble points of intersection: markets, stalls, shops. Each point marks a break: on one side is economic life with its commerce, its currencies ... on the other 'material life', the non-economy, imprisoned within self-sufficiency. The economy begins at the fateful threshold of 'exchange value'. (1982:21)

He contrasts the mentality of the merchant, who starts with money and buys goods only to sell them in order to acquire more money $\left(\mathrm{MGM}^{\prime}\right)$, with the mentality of the peasant, who comes to the market with goods to sell for money, but only as a means of acquiring other goods (GMG' ${ }^{\prime}$ ) (1982: 62-4). From the peasant's perspective, the transaction closely resembles barter, except that it is mediated by money. Thus Braudel's conception of material life includes the common 'things' of everyday life that are used or consumed primarily for their use values, even if these things have 


\section{JOURNAL OF WORLD-SYSTEMS RESEARCH}

been obtained from the market, as long as the buyer is primarily concerned with their use values rather than their exchange values.

Economic life, or the market, involves the exchange or circulation of goods according to set rules between relatively small buyers and sellers:

The economy, in the sense in which I wish to use the word, was a world of transparence and regularity, in which everyone could be sure in advance, with the benefit of common experience, how the processes of exchange would operate. This was always the case on the town market-place ... And it was the case too, even if the distance was greater, for any regular trade of which the origins, conditions, routes and markets were fixed. (1982:455)

He acknowledges that there are two different senses of the word market: "On one hand it is used, in a very loose sense, of all types of exchange that go beyond self-sufficiency ..." Thus we have urban markets or a gold market (1982:223). "On the other hand, the word "market' is often applied to a rather large broad form of exchange, also known as the market economy ..." (1982:223-4). "Historically, one can speak of a market economy, in my view, when prices in the markets of a given area fluctuate in unison ..." (1982: 227). This, Braudel thinks, has been the case in Europe since the twelfth century. The latter use of the word is what he is referring to when he speaks of economic life. Finally, because this market system was freely competitive and run by small traders and merchants, only small profits were earned; Braudel refers to it as "microcapitalism" (1981: 562).

The top layer of Braudel's schema is the zone of capitalism:

[T] he agents and men involved were not the same ... the rules of the market economy regarding, for instance, free competition as described in classical economics, although visible at some levels, operated far less frequently in the upper sphere, which is that of calculation and speculation. At this level, one enters a shadowy zone, a twilight area of activities by the initiated which I believe to lie at the very root of what is encompassed by the term capitalism: the latter being an accumulation of power (one that bases exchange on the balance of strength, as much as, or more than on the reciprocity of needs) a form of social parasitism ... (1982:22)

Braudel refers to it as the "anti-market" because the laws of the market do not apply here, or they apply only rarely. Consequently, this is the sphere in which the large profits are made. ${ }^{2} \mathrm{~A}$ defining characteristic of capitalism is its flexibility and adaptability. Opportunities for huge profits opened up at different times, in different places, and in different spheres of economic activity. Capitalists had to be ready to take advantage of the opportunities when they arose: "the characteristic advantage of standing at the commanding heights of the economy ... consisted

\footnotetext{
${ }^{2}$ For a detailed discussion of the distinction between the market and capitalism, see Wallerstein (2001: 207-17).
} 
precisely of not having to confine oneself to a single choice, of being able, as today's businessmen would put it, to keep one's options open." (1982: 381) During the period from 14001800 that Braudel was analyzing, capitalism's "home ground" was the long-distance trade, including the financing of this trade:

Long-distance trade certainly made super-profits: it was after all based on the price differences between two markets very far apart, with supply and demand in complete ignorance of each other and brought into contact only by the activities of the middleman. ... [I]f super-profits vanished from one line, it was always possible to find them again on another route with different commodities. $(1982: 405)$

Capitalism only occasionally entered into the sphere of production before 1800 . However, after the Industrial Revolution in the nineteenth century, capitalism found a new home ground in industrial production (1982: 231-49).

Since capitalism was based on power, it depended on the state. State power was necessary to suspend the rules of the market economy, to guarantee the monopolies, and to protect the super-profits of the capitalists. But state power was controlled by the capitalists: "The city-states ... were at this time tools completely in the hands of their merchants." (Braudel 1984: 51) Braudel considers Genoa and Amsterdam to have been city-states; Britain was the first territorial state to become a hegemon, but here, "England fell under the domination of its merchants fairly soon after the 1688 revolution" (Braudel 1984: 51), that is, well before its rise to hegemony. However, Braudel does acknowledge that there is the potential for conflict, because states and capitalism do not always have interests in common:

[T] he state undoubtedly encouraged capitalism and came to its rescue. But the formula can be reversed: the state also discouraged capitalism which was capable in return of harming the interests of the state. ... Capitalist interests, in the past as in the present, naturally extend beyond the narrow boundaries of the nation; and this prejudices, or at any rate complicates, the dialogue and relationship between state and capital. (1982: 554)

If Braudel only sketches the characteristics of, and the distinctions between, his three layers of analysis, he has even less to say about the connections between them. As Arrighi notes, echoing other critics, Braudel "does indeed describe more than he theorizes." (2001: 120) However, it is an exaggeration to say, as Tilly does, of Braudel's three-layer conceptualization: "It does not, however, reflect a causal hierarchy. It does not unfold a tight analytical model that guides the movement from one analysis to the next." (1984: 66) There is a causal analysis in Braudel, but like his descriptions of the three layers, it is scattered through his work. It is complex and contingent, and maybe not as "tight" as Tilly would like. However, it is not clear whether a "tight" causal model can really explain the broad sweep of historical time that both Braudel and Arrighi seek to deal with.

On the one hand, first the market and later capitalism grow out of the base of material life. As population increased, a division of labor became necessary, leading to the growth of towns and the need to exchange goods. The existence of towns required a supply of food from the 


\section{JOURNAL OF WORLD-SYSTEMS RESEARCH}

surrounding countryside, exchanged for goods produced in the towns. Markets were taken over by the towns, increased in number and became specialized (1981: 480-1; 1982: 25-44, 600-1). Gradually, various forms of private trading developed to evade the tightly controlled town markets and make larger speculative profits (1982: 45-9). But it was the opportunities for huge profits opened up by the long distance trade in the wake of European attempts to conquer the rest of the world that led to the birth of capitalism (1982:600-1).

On the other hand, once all three layers had been established, influence flowed primarily from the top down. The lower level of material life was a world of unthinking routine which was highly resistant to change. He calls it "this layer of stagnant history" (1981: 28). As the market economy expanded, more and more of the goods which were part of material life passed through the market, gradually changing the way people thought about them. A decisive development was the creation of labor markets: "The peasant who was paid a wage, ... even if he received so much of his pay in kind that he practically never had two coins to rub together at the end of the year, had grown accustomed to reckoning in money terms." (1982:59) Thus the market slowly invaded and reshaped some of the layer of material life, rolling back its boundaries; but large parts of it still remained outside of economic life. However, it was the layer of capitalism that exerted the most influence on the other layers. The capitalists:

... could manipulate exchange to their advantage and disturb the established order. ... [T] hey created anomalies, 'zones of turbulence' and conducted their affairs in a very individual way. At this exalted level, a few wealthy merchants ... could throw whole sectors of the European or even world economy into confusion, from a distance. (1981: 24)

Further:

In a context where other structures were inflexible (those of material life and, no less, those of ordinary economic life) capitalism could choose the areas where it wished and was able to intervene, and the areas it would leave to their fate, rebuilding as it went its own structure from these components, and gradually in the process transforming the structures of others. (1981: 562)

Even the expansion of the market economy was often (though not always) driven by the top layer. During the sixteenth century, fairs spread across Europe. Braudel argues that "progress forward in the sixteenth century must have been achieved from above, under the impact of top-level circulation of money and credit, from one fair to another. Everything else would have depended on these international monetary movements ..." (1982:135).

Braudel does note a couple of exceptions to this top-down causation. First, the layer of material life could be a site of active resistance against the forces of capitalism and the market:

[T] he market economy had ... been a restrictive order, and, like all restrictive orders, ... it had created an opposition, counter-forces, both above and below itself. ... [F] 
of a modern version of the non-market economy: hardly disguised forms of barter, the direct exchange of services ... (1981:24-5).

Nowadays, on the other hand, if there is a substantial sector outside the 'economy' or outside the market, it is more likely to reflect a refusal from below ... (1982: 28-9).

Second, economic life is the main source of innovations that are later adopted by capitalism:

The lowest level, not being paralyzed by the size of its plant or organization, is the one readiest to adapt; it is the seedbed of inspiration, improvisation and even innovation, although its most brilliant discoveries sooner or later fall into the hands of the holders of capital. (1984:631)

There is a clear causal hierarchy here; capitalism shapes the two lower layers much more than they shape capitalism. Further, the market tends to invade and colonize material life more than material life alters the functioning of the market. However, this does not preclude some causal influence from working in the opposite direction during certain conjunctures.

In this article, I seek to contribute to the research program set out by Arrighi, by venturing down from the heights of capitalism's systemic cycles of accumulation into the aspects of material life and economic life connected to the coffee commodity chain. I investigate how the coffee commodity chain evolved through Arrighi's four systemic cycles and to explore the connections between Braudel's three layers of analysis through this evolution. Coffee is an apt commodity for this type of analysis. It was introduced into Western Europe by Venetian traders during the Genoese systemic cycle, and has played an important role in the shaping of material life, the market economy, and capitalism as a system ever since. The coffee commodity chain is the linked sequence of activities involved in growing coffee, processing it, shipping it, roasting it, and selling it to consumers. Some of these activities, such as growing coffee or consuming it, may be phenomena of material life, while others, such as the transactions that move coffee along the chain from the grower to the exporter to the importer to the consumer, are primarily phenomena of the market economy. The overall structure and organization of the chain are often decided at the level of capitalism. The commodity chain as a unit of analysis thus encompasses activities at all three of Braudel's levels, within a structure that links them together so that a change in one activity is likely to spark changes in all other linked activities. The commodity chain is therefore an ideal unit of analysis with which to explore the connections among Braudel's three levels.

The introduction of an agricultural commodity into Braudel's conceptualization illuminates a fourth layer that serves as the foundation of his three-story house: the ecological layer. Although Braudel begins the first volume of the Civilization and Capitalism trilogy by introducing the concept of the biological regime, it does not play a major role in his analysis thereafter (Moore, 2003:42-5). However, there are several ecological characteristics of coffee production that impinge on the market, and through it, on material life and capitalism. First, coffee is a tree crop that takes 3-5 years after it is planted to begin producing; this means that coffee production responds relatively slowly to price signals emanating from the market economy. Thus coffee growers collectively tend to over-plant during periods of high prices, since the planting of new trees has no immediate effect on price levels. This over-planting typically 


\section{JOURNAL OF WORLD-SYSTEMS RESEARCH}

leads to oversupply and falling prices 3-5 years later. Second, coffee tends to produce cyclically; a heavy crop one year is followed by a lighter crop in the following year. These supply fluctuations can also cause price fluctuations in the market. In addition, coffee is susceptible to a variety of pests and diseases, and it is sensitive to environmental variations in rainfall and temperature; all of these factors can influence the amount of coffee that a tree will produce. All of this means that the amount of coffee produced from year to year and region to region can fluctuate rather widely and unpredictably, introducing a measure of uncertainty into the calculations of the market economy, and opening opportunities for speculation by capitalists (Talbot 2004: 31-5). Capitalism and the market also impinge on the ecological layer. Coffee was often planted on forested land cleared by slash and burn techniques; this facilitated erosion and rapid exhaustion of soil fertility, driving the growers further into the forest to clear more land to meet the demands of the market and the capitalists for more coffee (Tucker 2000).

\section{THE GENOESE SYSTEMIC CYCLE}

Arrighi's first, or Genoese, systemic cycle of accumulation began in the mid-fifteenth century and extended through the $16^{\text {th }}$ century into the early $17^{\text {th }}$ century. It was characterized by a relationship of political exchange between Genoese capitalists and Iberian rulers. The Genoese controlled European and Atlantic trade and provided the financing, and the Iberians provided military power and protection of trade routes, as well as an expanding New World empire from which to draw commodities for trade (Arrighi 1994: 109-32).

During the Genoese cycle, coffee was mainly an Islamic beverage, and its commodity chain was located outside the European world-economy. Although the origins of coffee drinking are obscure, it is fairly well established that coffee drinking was popular among the Sufis of Arabia Felix, now known as Yemen, by the fifteenth century. From there, during the sixteenth century, coffee drinking spread north through the Arabian Peninsula and beyond, reaching Cairo in the early $1500 \mathrm{~s}$ and Istanbul around 1550 . At the same time, although much less well documented, the coffee drinking habit was spreading east through Persia to India and west through northern Africa (Topik 2003: 26-7; Ukers 1935: 17-8). At first, the coffee probably came from Ethiopia, the place where arabica coffee is believed to have originated, where it was picked from wild bushes. As demand for coffee grew, peasant farmers in Yemen began to cultivate the crop in the mid sixteenth century (Wrigley 1988: 1-4; Hattox 1985: 12-26; Tuchscherer 2003: 502). Thus, during this time, coffee was an Islamic beverage, a commodity that circulated within a world-system separate from the European one (Braudel, 1984: 467-84).

The early coffee trade centered on the Red Sea port of Mocha, near the main area of coffee cultivation; Indian merchants carried it east from there, Egyptian merchants carried it north through the Red Sea, and Arab and Turkish merchants carried it overland through the Ottoman Empire (Wrigley 1988: 16-7; Hattox 1985:26-8; Tuchscherer 2003: 52-5). Although we know very little about these early non-European traders, it is likely that they, like the European longdistance traders, were motivated by large profits that could be made by carrying coffee from Mocha to distant cities where it was in demand (Hattox 1985: 72-3, 79; Tuscherer 2003: 53-4). However, the merchants in Mocha who sold the coffee probably also made considerable profits, because they enjoyed a monopoly on its supply, which they jealously guarded (Wild 2004: 75-6; Wrigley 1988: 38; Tuscherer 2003: 54-5). 
In those early Islamic cities where coffee drinking became popular, it sparked a change in the material lives of the citizens: the rise of the coffeehouse. Hattox (1985) argues that coffee drinking spread not only because of the nature of the beverage itself, but because of the social rituals that grew up surrounding its consumption. "One went to the coffeehouse not merely because one wished to drink coffee. One went to the coffeehouse because one wished to go out, to spend the evening in the society of his fellows, to be entertained, to see and be seen." (89-90) Hattox argues that this was a new phenomenon in Islamic cultures, where all meals were prepared and eaten in the home, and the only public venue available for socializing was the tavern, where no devout Muslim could afford to be seen. This social aspect of coffee drinking was also what led to periodic attempts by various rulers to ban the beverage as unacceptable under Islamic law; what the rulers were really concerned about, Hattox (1985: 91, 100-3) argues, was what those gathered at the coffeehouse were talking about, and where that talk might lead.

Once coffee drinking had become established in cities like Cairo and Istanbul, it was encountered by European travelers, who brought back stories of the hot, dark brew consumed by the Arabs (Wrigley 1988: 12; Ukers 1935: 18-9). Venetian merchants, who controlled the eastern Mediterranean trade (Arrighi 1994: 91, 115), were probably the first to bring coffee into Western Europe, around 1600, from Alexandria or Istanbul. The Dutch first imported coffee from Mocha into Amsterdam in 1616 (Wrigley 1988: 16, 24). During the latter half of the seventeenth century, coffee drinking would spread through the major urban centers of Europe.

Coffee thus entered the European world-economy toward the end of the Genoese cycle, as one of the many exotic products being brought in by explorers and traders. It was a novelty, probably consumed by a few small groups of very wealthy individuals in the major cities. However, there was a thriving coffee commodity chain during this cycle, which connected production in Ethiopia and Yemen with consumption located throughout the Islamic world and beyond. From what little we know about the chain during this period, it seems probable that its growth was driven by changes in material life. The cultural innovation of the coffeehouse led to increasing demand for coffee. Once the coffee drinking habit had spread beyond Yemen, coffee necessarily became a marketed commodity, since it was not grown in the other places where it was consumed. However, there was not yet a market economy in Braudel's sense, with prices moving in unison in the different urban coffee markets. This opened the opportunity for large profits to be obtained by the Mocha merchants and the long distance traders who served as the middlemen, both capitalist in the Braudelian sense of using market power to obtain super-profits. Where the European world-system of the Genoese cycle intersected with this non-European trade circuit, in the eastern Mediterranean, Europeans "discovered" coffee and began to use it. Its consumption would spread rapidly through Europe during the Dutch cycle, and the major world powers would begin to restructure the commodity chain and incorporate it into the expanding European world-system.

\section{THE DUTCH SYSTEMIC CYCLE}

Arrighi dates the second, Dutch-led systemic cycle of accumulation from c. 1640, after the United Provinces won independence from Spain and used their control over the Baltic trade in grains and naval stores to consolidate their position as the hegemonic power in the world-economy. Dutch hegemony was again based on an alliance between political/military and economic powers, but 


\section{JOURNAL OF WORLD-SYSTEMS RESEARCH}

this time within the territory of the United Provinces. The organizational innovation of the Dutch that allowed them to surpass the Genoese was the internalization of the protection costs involved in protecting their trade routes. The material expansion of the Dutch cycle lasted through the mid$1700 \mathrm{~s}$, followed by a financial expansion through the rest of the century. By the $1790 \mathrm{~s}$, Britain had taken over as the hegemonic power in the world-economy (Arrighi 1994: 132-44).

Once coffee had been "discovered" during the Genoese cycle, its use spread rapidly during the Dutch-led material expansion. One chronology of the first openings of coffeehouses in major cities illustrates this: Venice 1645, London 1652, Marseilles 1659, Amsterdam 1663, Paris 1675, Hamburg 1679, and Vienna 1683 (Burgin 1978, cited in Wrigley 1988: 32). These coffeehouses were meeting places for political, economic, and literary elites, but were also frequented by not-so-wealthy middle classes and professionals (Wrigley 1988: 24, 28-9; Heise 1987: 37). As coffee drinking spread through Europe, it also spread to new and larger segments of the population. Demand for coffee therefore must have grown fairly rapidly during the Dutch period of material expansion. ${ }^{3}$

At the beginning of this period, Yemen was still the only place in the world where coffee was grown commercially (although wild Ethiopian coffee was also being imported into Yemen for local consumption and for re-export), and its merchants enjoyed a monopoly (Tuscherer 2003:54-5; Wild 2004: 75-6). But the growing demand for coffee, and the opportunities to profit from its trade, led the Dutch and the French to attempt to break Mocha's monopoly on the trade, by creating new sources of supply more directly under their control.

The first important commercial plantings of coffee outside Yemen were made by the Dutch in the 1690s, in Java and Ceylon. ${ }^{4}$ During the $1720 \mathrm{~s}$, Java eclipsed Mocha as the major source of coffee for the Amsterdam market, Europe's most important (Wrigley 1988: 16; Topik 2003: 28). However, the Dutch strategy was also to focus on trade, not production (Arrighi 1994: 150-8). They devised a system to force Javanese peasants to produce coffee by using local rulers as their agents. They signed agreements with these rulers obliging them to deliver a set amount of coffee to the VOC (the Dutch East Indies Company) at a fixed price. These local rulers then forced peasants under their control to grow the coffee (Fernando 2003: 159; Ukers 1935: 40). The Dutch also attempted to enhance their trading profits by creating a monopoly of supply. They were able to do this forcibly for the spice trade in the East Indies (Arrighi 1994: 150-8), but were unable to eliminate Mocha as an alternate source of supply for the coffee trade. However, they did try to use their control over the supply from Java to augment their control over the Indian Ocean trade, undercutting the Indian merchants who had previously controlled it $^{5}$ (Topik 2003: 27-8; Wild 2004: 98-100).

Dutch attempts at controlling the supply of coffee were short-lived. Once the Dutch broke the Arab monopoly, another rising mercantilist power, France, also got into the business of globalizing coffee cultivation. They introduced coffee to the island of Bourbon (now Réunion) in 1715 , and it rapidly, if briefly, became a major coffee producer. Here coffee was grown directly

\footnotetext{
${ }^{3}$ This was rapid growth from a very small base, so that even at the end of the Dutch cycle, total consumption was fairly low by modern standards, and it was found only among the urban upper and middle classes.

${ }^{4}$ Some coffee had probably been planted earlier along the southwest (Malabar) coast of India, but it is unclear by whom, and this coffee was not an important factor in world trade at this time.

${ }^{5}$ Even before coffee drinking took off in Europe, the VOC was profiting from the Indian Ocean trade, carrying coffee from Mocha to India.
} 
by French planters using slave labor (Campbell 2003: 68-9). This exemplified the French and British mercantilist strategy, which was soon to overtake the Dutch, of exerting direct control over production (Arrighi 1994: 176-7). The labor necessary to pursue this strategy was supplied by slavery.

From these beginnings in Java and Bourbon ${ }^{6}$, coffee quickly spread to the New World, but via Europe. Coffee was raised in the Amsterdam and Paris botanical gardens, and seedlings from these plants were carried to Surinam by the Dutch in the early $1700 \mathrm{~s}$, and to Martinique by the French in the $1720 \mathrm{~s}$. Surinam and Martinique would be the source for most, if not all, the coffee trees that diffused throughout the Americas in subsequent centuries (Wrigley 1988: 40-7; Ukers 1935:2-5). From Martinique, coffee was introduced into Saint-Domingue (Haiti), which became a major producer in the second half of the century, until the 1791 revolution (Trouillot 1982: 337-8). The British also introduced it into Jamaica in about 1730 (Ukers 1935: 70), but Jamaica only became a major producer, briefly, after a slump in world sugar prices and the arrival of Saint-Domingue planters driven out by the revolution, in the early $19^{\text {th }}$ century (Delle 1998 : 50-2). Coffee from Surinam or French Guiana was introduced into Brazil in the 1720s, and coffee from these and other sources spread through other Caribbean, Central and South American colonies in the latter half of the $18^{\text {th }}$ century (Wrigley 1988: 46-50; Ukers 1935: 5). Latin Americans would become the world's major producers only after their countries achieved independence in the $1820 \mathrm{~s}$. All of these developments during the Dutch cycle brought the coffee commodity chain more firmly under European control. Consumption spread through Europe, and most production was now within the boundaries of the expanding European world-economy (Trouillot 1982: 339-40). But the spread of production itself was also a part of the outward expansion of the boundaries of the system, as new areas of the world outside of Europe were linked to the core of the system, as suppliers of coffee. ${ }^{7}$

As was the case for the Islamic-controlled commodity chain during the Genoese cycle, the main driving force behind the development of this new, European-controlled coffee commodity chain was at the level of material life. Just as the coffeehouse filled a social need in Islamic societies, so it did in European cities. As coffeehouses spread through Europe in the second half of the $17^{\text {th }}$ century, demand increased, but Mocha was still the only source of coffee. The long-distance traders were the key connections between these export and import markets. European coffeehouse owners had no direct knowledge of coffee production or of the supply available in Mocha; and the Arab merchants in Mocha who sold it could only infer information about final demand for coffee in Europe from the amounts purchased by the traders. Further, there were no regular markets for coffee in the early days of this trade. The arrival in Mocha of a European trader wanting to buy coffee raised local prices (Wrigley 1988: 16). Conversely, the arrival of a new load of coffee in Amsterdam probably depressed local prices (Topik 2003: 29).

\footnotetext{
${ }^{6}$ The names of these earliest coffee production sites were used to denote types of coffee in the early trade, and they have become a part of contemporary coffee lingo. Mocha is still used to denote the type of coffee grown in Yemen, and is often applied to coffees with similar taste characteristics. Java became an American slang word meaning coffee in general, as well as denoting coffee produced on the island of Java, which is a constituent of the oldest and best known coffee blend, Mocha Java. Bourbon today is used to denote a specific variety of Arabica coffee tree, supposedly a direct descendant of the trees that were brought from Bourbon to Martinique by way of Paris.

${ }^{7}$ This process involved other commodities besides coffee; foremost among them sugar, which was the main plantation crop of both Saint-Domingue and Jamaica.
} 


\section{JOURNAL OF WORLD-SYSTEMS RESEARCH}

But there was little correlation between prices in Mocha and Amsterdam. This created a situation in which the traders, the only ones who had some information about both supply and demand, were able to make large profits by maximizing the spread between the purchase price at Mocha and the selling price in Amsterdam.

All of this made the coffee trade part of the "home ground" of capitalism, in Braudel's terms. This trade also provided the impetus for capitalism to venture into the realm of production. By gaining control over the supply of coffee, long distance traders could lower the purchase price and eliminate the uncertainties associated with buying coffee from Mocha. While the Dutch capitalists did not invest directly in production, but worked through Javanese intermediaries, the French and British capitalists did move into production, initially in Bourbon and Jamaica, respectively. However, this spread of production through the newly colonized areas would not have been profitable without expanding European demand. As Europeans gained more control over production and the supply of coffee increased, the trade became regularized, competition increased, and the rate of profit declined. Topik (2003: 29) argues that the world coffee market became more integrated by the second half of the $18^{\text {th }}$ century, and that prices in Amsterdam became more stable. In addition, with rising consumption, the volume of coffee flowing into Europe increased substantially. All these factors combined meant that the Amsterdam coffee market was a more competitive market by the end of the $18^{\text {th }}$ century. In Braudel's terms, then, the coffee trade became a part of the market economy. This shift of coffee from the realm of capitalism down to the level of the market economy roughly coincides with the transition from the material expansion of the Dutch cycle to its financial expansion.

The social aspects of coffee consumption embodied in the coffeehouses seem to place them at the level of material life, according to Braudel's definition. But the relationship between capitalism, the market, and material life in the coffeehouse phenomenon was much more complex. It illustrates the difficulty of separating the three layers in Braudel's schema, even at this relatively early period in the history of the European world-economy. This is best documented for the London coffeehouses, which I discuss presently, although similar social processes were probably happening in other major European cities at this time as well (Heise 1987: 130-40; Wrigley 1988: 33; Ukers 1935: 93-100). First, coffee, as a tropical crop, could never be a part of Europe's informal, subsistence economy. If the Europeans wanted coffee, they had to venture to the tropics to get it. This meant that European coffee drinkers were integrated into a world market. Even so, we can still place coffee drinking firmly within the level of material life, since the stimulative effect of the brew and the sociability of the coffeehouses were the main reasons that people consumed coffee. They did not value it for its exchange value, but for its use value.

Coffeehouses also became meeting places for merchants and others, where important business was conducted. Perhaps most famous was Edward Lloyd's coffeehouse, which was frequented by merchants engaged in long-distance trade, ship owners, and insurance underwriters. The ad hoc deals arranged in this coffeehouse would in time evolve into Lloyd's of London (Ukers 1935: 80-1; Wrigley 1988: 28; Schivelbusch 1992: 49-51). Jonathan's and Garraway's became meeting places for stock brokers, and the birthplaces of the London Stock Exchange (Wrigley 1988: 28). The Jerusalem Coffee House was a gathering place for agents of the East India Company (Wild 2004: 86). Heise (1987: 128) argues that "the coffee-house lent major impetus to the evolution of the bourgeoisie from a class in itself to a class for itself, and to the latter's emancipation from the aristocracy and the clergy." While this may be a bit of hyperbole, it 
is clear that major institutions of the market economy, as well as strictly capitalist ventures, were organized through the coffeehouses. Here we see all three of Braudel's layers interwoven in a way that is very difficult to separate, even analytically. When a ship owner and a merchant who were planning a voyage to China went to Lloyd's, bought cups of coffee, and sat down with an underwriter to negotiate insurance for the trip, as well as to discuss current affairs, was this material life, the market, or capitalism?

The impact of coffeehouses on society went well beyond the economic. Political, literary, and scientific elites all had their favorite, "specialized," meeting places. The Royal Society was founded in Tillyard's Coffeehouse, which was frequented by scientists such as Edmund Halley and Isaac Newton (Wild 2004: 89-90; Wrigley 1988: 25). Richard Steele's Tatler and Joseph Addison's Spectator emerged from Button's, one of the leading literary coffeehouses, and they gathered material for their journals at various other coffeehouses (Heise 1987: 131; Wrigley 1988: 29; Ukers 1935: 75-6). Republicans met at the Turk's Head Coffeehouse, while the Royalists met at Tillyard's; Whigs met at St James', while Tories met at the Cocoa Tree (Wild 2004: 88-92; Ukers 1935: 55-6; Wrigley 1988: 30). Coffeehouses became known as "Penny Universities," because the price of admission was often one penny, while a cup (or dish, as it was called) of coffee could be had for one or two pennies more. For this price, one could listen to, or participate in, discussions of the great ideas of the time, often involving some of the leading minds of the time (Ukers 1935: 69-70; Wild 2004: 87). It could be argued that the coffeehouses were incubators of what today would be called civil society, a potential counterweight against the forces of the market, hence, a part of material life for Braudel. Material life does not just roll back and weaken under the onslaught of capitalism and the market economy, but retains the ability to rejuvenate and expand in new ways.

While the development of a European-controlled coffee commodity chain had many positive effects on material life in Europe, the effects on the material lives of those peoples incorporated into the expanding world-system through coffee production were certainly disastrous. The penetration of capitalism into their material lives led to the imposition of coffee cultivation in Java, in the more benign case. Javanese peasants surely resented the imposition, but little is known about their reactions to it during this early period. The evidence suggests that their resistance was mostly passive. Yet the Dutch were able to obtain significant amounts of coffee through this system (Fernando 2003).

In the other early colonies where coffee was grown with slave labor, the effects are widely known. Africans were ripped from their old material lives and transplanted to completely different ones in plantation-slave economies in Reunion and the Caribbean, and later Brazil, in order to produce coffee for the European markets. This was the epitome of capitalism, throwing "whole sectors of the ... world economy into confusion, from a distance." (Braudel 1981: 24) There were revolts and rebellions against this destruction of material life by capitalist forces, most notably the Haitian revolution. Sugar was a more important force behind the development of these slave economies and the rebellions against them, but coffee also played an important role. Trouillot (1982) argues that it was the introduction of coffee into Haiti that destabilized the sugarplantation slavery system and made the revolution possible.

Coffee consumption appears to have grown rapidly during the material expansion of 1640-1740. This opened the possibility for super-profits to be earned by capitalists, first by controlling trade, and later by controlling production. This led to the global expansion of coffee production and the incorporation of new regions into the expanding world-economy. During the 


\section{JOURNAL OF WORLD-SYSTEMS RESEARCH}

financial expansion of the late $18^{\text {th }}$ century, this growth appears to have tapered off. Coffee consumption had probably saturated the markets among the urban upper and middle classes in Europe, and the slowing of growth in demand probably made it less urgent to secure new sources of supply. Profitability in the coffee trade was also lower, removing incentives to bring new areas into production. Profits continued to be made from the coffee trade, but they were probably increasingly invested in other financial dealings. It would take the spread of coffee consumption to the working classes during the British cycle to set off a new round of expansion.

\section{THE BRITISH SYSTEMIC CYCLE}

By the $1790 \mathrm{~s}$, Britain had displaced the United Provinces as the hegemonic power in the worldeconomy. The organizational innovation that propelled the British forward was the internalization of production costs, achieved by bringing the peripheral areas where the raw materials for British industry were produced within the expanding boundaries of the British Empire. The material expansion of the British cycle stretched through the $1870 \mathrm{~s}$, with two distinct phases. For the first 50 years, the "endless accumulation of capital" was achieved through investment in expanding industrial production in Britain. However, beginning in the $1840 \mathrm{~s}$, there was a massive export of British capital to peripheral areas. This in turn stimulated a massive increase in raw material flows back to Britain. The financial expansion began in the Great Depression of 1873-96 and ended in the Great Depression of the 1930s (Arrighi 1994: 159-74). Latin America was one of the major destinations for the exported British capital, which touched off an export boom of raw materials from Latin America to Europe and North America. Coffee was the most important export of Latin America during this boom (Topik and Wells 1998: 8; Topik 1998: 38).

Once again during the British cycle, the uses of coffee in material life seem to have been the driving force behind the expansion and reorganization of the coffee commodity chain. Coffee consumption spread from the middle and upper classes to the new industrial working classes being created by the industrial revolution. Ironically, despite the central role of British capital in the Latin American export boom, most of the coffee exports did not go to London. British mercantilists and the state had built their economic and military power on the trade of tea from $\mathrm{China}^{8}$, sugar from the Caribbean, and slaves from Africa to produce the sugar. When the Industrial Revolution created a large working class in Britain in the early $19^{\text {th }}$ century, tea with sugar provided an important part of their sustenance (Mintz 1985: 110-9). ${ }^{9}$ However, the situation in the other industrializing core powers was different, and coffee became the beverage that kept workers awake for long hours in the factories. Most important among these was the U.S., whose break from Britain was symbolized by the Boston Tea Party, confirming its national identity as a coffee-drinking country (Ukers 1935: 102-3; Wild 2004: 127-38). During its early industrialization, between 1830 and 1900, U.S. per capita coffee consumption rose from three to

\footnotetext{
${ }^{8}$ The British began planting tea in India only after they had achieved hegemonic status, in the 1830 s. And although Britain had been a major coffee consuming country in the second half of the seventeenth century, by the early eighteenth century, tea had replaced coffee as the hot beverage of choice. This change was driven by the East India Company and the state, which both derived far more revenues from tea than from coffee (Mintz 1985:110-9; Schivelbusch 1992: 79-84: Ukers 1935: 70).

${ }^{9}$ In a parallel with coffee, this expansion of tea consumption encouraged the British East India Company to break China's monopoly on the supply of tea by planting it in India.
} 
thirteen pounds annually (Jimenez 1995: 39-40). France and Germany were the major European coffee importers (Samper and Fernando 2003: 443). The British still traded in coffee, and London was a major coffee port because it was the financial center of the world, but it served mainly as an entrepôt for the European trade (Topik 2003: 39).

During the Dutch cycle, coffee had been introduced into most of the major regions of the world where it could be grown. During the British cycle, the late entrants surpassed the older, established producing regions. The Caribbean had become the most important coffee-growing region toward the end of the Dutch cycle, with Saint Domingue being the largest producer up to the time of the revolution. After the revolution, the center of Caribbean coffee production briefly shifted to Jamaica and Cuba, before Haiti recovered its position as a major producer by the $1820 \mathrm{~s}$ (Samper and Fernando 2003: 428). ${ }^{10}$ Coffee had been introduced into many Latin American countries from the Caribbean during the late $18^{\text {th }}$ and early $19^{\text {th }}$ centuries, but had not become a major product. The most important early producers were Brazil, Venezuela, and Costa Rica, but none were major exporters until the $1820 \mathrm{~s}$. Colombia, Guatemala, El Salvador, Nicaragua, and Mexico became significant producers toward the end of the $19^{\text {th }}$ century (Roseberry 1995: 6, 11; Samper and Fernando 2003: 424-35). It was not until the countries of Latin America won independence from Spain and Portugal that the center of world coffee production shifted there. Brazil rapidly emerged as the dominant producer.

The mass consumption of coffee in the U.S. and Europe, and the mass production of coffee in Brazil, were mutually reinforcing developments. Brazil's supply of huge volumes of relatively cheap coffee was the precondition for the rapid expansion of coffee consumption by the working classes. At the same time, Brazil could not have expanded production so rapidly, and achieved economies of scale in production and transportation, if not for the growing demand for coffee among European and American working classes (Topik 2003: 31-8). While U.S. per capita coffee consumption rose from three to thirteen pounds, Brazilian coffee exports increased from 30,000 to 600,000 metric tons (Samper and Fernando 2003: 432-3).

Brazilian production was based on slave labor for most of the $19^{\text {th }}$ century. The importance of coffee to the economy, and the importance of slave labor to coffee production, may have delayed the abolition of slavery, which didn't happen until 1888 (Topik 1998: 43). This was one factor in the cheapness of Brazilian coffee. But an equally important factor was the availability of huge expanses of virgin land that could be cleared and planted in coffee (after the indigenous inhabitants had been removed). These new plantings were considerably more productive than land that had been under coffee cultivation for many years. ${ }^{11}$ Here British capital played the crucial role, supplying the capital necessary to build an extensive railway network. The new railroads opened up virgin lands in the interior to coffee cultivation and made the transport of

\footnotetext{
${ }^{10}$ Jamaican production declined drastically in the 1830s; Cuban production did the same in the 1840s.

${ }^{11}$ An additional factor was the way Brazilian coffee was harvested and processed. It was harvested by stripping the branches of the trees, collecting ripe and unripe cherries together, rather than picking only the ripe cherries. This method meant that all the coffee could be picked with one pass through the trees, rather than the several passes required by the method of picking only the ripe cherries. It also meant that less skilled labor was required. The coffee was processed by the dry method, in which the cherries were dried in the sun and then the cherry, parchment and silverskin coatings were all removed in one hulling operation. This was cheaper than the wet processing method, in which the fresh cherries were depulped, fermented, washed, and then dried, and the parchment and silverskin coatings removed in a later, separate hulling operation. The Brazilian method produced coffee of lower quality, but at a significantly lower price.
} 


\section{JOURNAL OF WORLD-SYSTEMS RESEARCH}

massive quantities of coffee to the ports economically feasible. Beginning in the middle of the $19^{\text {th }}$ century, the steamship revolution also made transportation from Brazilian ports to Europe and the U.S. somewhat cheaper, much quicker, and more reliable (Topik 2003: 31-6; 1987: 59$63)$.

The coffee commodity chain shifted geographically in this cycle. The archetypal coffee trade route during the Dutch cycle had been Java to Amsterdam; under the British cycle it was Brazil to New York. The form of transactions also shifted. Mercantilist transactions that operated within imperial spheres gave way to market transactions between U.S. and European trading firms and Latin American exporters. ${ }^{12}$ It seems that rising hegemons are already testing and perfecting their organizational innovations well before they attain hegemonic status. The British (and French) were already internalizing production costs through colonial coffee production during the Dutch cycle, and during the British cycle, the U.S. was perfecting a new form of neocolonial domination of nominally independent nations. Already, there was heavy U.S. and European participation in the Latin American export firms (Topik 1998: 58-60). This allowed the traders to drive down export prices and maximize the price spreads between export and import markets, thus earning large profits. Finally, the volume of coffee flowing through the chain also expanded dramatically as coffee went from a luxury item to a mass consumption good.

The British cycle represents a major change from the Dutch in the relative importance of material life, the market, and capitalism. Capitalism moves into new home grounds, the layer of the market greatly expands, and consequently, the layer of material life recedes. With the coming of the Industrial Revolution, capitalism began to radically restructure the material lives of the vast majority of the population that had been confined to that "layer of stagnant history" (Braudel 1981:28). As peasants were drawn or driven off the land and into the factories to become the new working class, they needed a stimulant to get them up in the morning and keep them awake through a long working day. While tea provided that stimulation in Britain, coffee provided it in Continental Europe and the U.S.. Consequently, there are important differences between the ways that coffee was used by the upper classes in the coffeehouses of the Dutch cycle and by the working classes of the British cycle. Coffee began to move out of the coffeehouse and into the home (Jimenez 1995: 39-41). As a result, the focus of coffee consumption moved from the social rituals surrounding it to the physical effects of the beverage. This changed the way people thought about coffee, from a beverage that promoted alertness and mental agility for conversation and debate, to a much more instrumental orientation: coffee was an aid that helped them to earn a wage. In other words, coffee drinking began to move out of the realm of material life and into the realm of the market economy.

Capitalism had already relinquished the long distance trade in coffee by the financial expansion of the Dutch cycle, as the trade became more regular and competitive. During the British cycle, a few capitalists who managed to gain market power in both exporting and importing markets were able to manipulate the markets to earn large profits, but trade was no longer the main locus of capitalism. It had been involved in the spread of colonial production during the Dutch cycle, but this option also began to decline during the British cycle. Capitalism now moved directly into production, in Brazil. The increasing demand for coffee by the growing U.S. working class was expressed at the level of the market economy. Brazilian planters read

${ }^{12}$ Some mercantilist transactions between European colonial powers and their colonies continued, but they were no longer the most important ones. 
these market signals, realized that there was money to be made from coffee, and greatly expanded their production. In the process, they created a demand for British capital goods in the form of iron to build the railroads, at a time when British capitalists were looking for investment opportunities outside Britain in order to continue their accumulation of capital. I refer to the Brazilian planters as capitalists in Braudel's sense of the word, because they based their production on slave labor to minimize costs, and because they took over and cleared massive tracts of new land to plant coffee. Both required the exercise of power (in alliance with the state) and enabled the planters to earn profits larger than they would have on a competitive market (Dean 1969: 6). However, these were peripheral capitalists; they were producing for a world market controlled by Brazilian export firms (many foreign controlled) and U.S. and European import firms. They could not set their own prices for the coffee, and hence probably did not earn super-profits. Further, the financing required for this venture was beyond the capacity of local capital and the state, hence the necessity of drawing in British capitalists to help build the railroads, and share in the profits. However, as a result of this process, the Brazilian planters were able, by the late $1800 \mathrm{~s}$, to construct a near-monopoly in coffee production, through which they would attempt to exert their market power.

Once again, these changes at the level of the market economy, as well as at the level of capitalism as a system, had impacts on the material lives of the people growing the coffee. In the case of Brazil, coffee was grown by slave labor until abolition in 1888, although the importation of colonos had begun in the 1870s (Dean 1969: 35-6). Under the colono system, the state subsidized the importation of European workers to work the plantations under one-year contracts. This resulted in "the only instance in history in which massive numbers of Europeans crossed the Atlantic to work on semitropical plantations." (Topik 1998: 45) Since the colonos were free to move after the ends of their contracts, and since the rapid expansion of coffee created severe labor shortages, the colonos were much better treated than the slaves had been (Topik 1998: 4850; Dean 1969: 42). Many colonos worked the plantations for only as long as it took them to acquire their own land; thus the colono system led to the growth of a sector of independent, small-to-medium size, market-oriented farmers alongside the plantation sector ${ }^{13}$ (Font 1990: 1122).

As Brazilian production grew to over $50 \%$ of total world production by the $1850 \mathrm{~s}$, events in the Brazilian coffee regions became more closely linked with developments in the coffee markets of the U.S. and Europe. The use of steamships to transport the coffee and the use of transatlantic cables to transmit information about coffee supplies and prices made this linkage much tighter than it had been during the Dutch cycle (Topik 2003: 32-4). Under these conditions, the ecology of coffee production, which caused wide variations in Brazilian production, could have effects similar to capitalism, throwing "whole sectors of the ... world economy into confusion, from a distance" (Braudel 1981: 24). The instability of supply helped to make coffee an object for speculation by capitalists in the main consuming market, the U.S.. An alliance of three large import firms, known as the Trinity Syndicate, manipulated prices through the $1870 \mathrm{~s}$

\footnotetext{
${ }^{13}$ However, the small-to-medium sized farms in Brazil would have been considered large to very large in most other coffee growing countries. Font (1990: 17, 282-3) defines smallholders as owners of less than 20,000 coffee trees. He estimates that this translates into a farm of less than 60 hectares. And these "smallholders" only produced $30 \%$ of Brazil's coffee by 1930 , so in the late 1800 s, coffee was still a plantation crop.
} 


\section{JOURNAL OF WORLD-SYSTEMS RESEARCH}

by buying up large amounts of coffee to create artificial shortages. When the syndicate collapsed in $1880-81$, its losses were variously estimated at between $\$ 5$ and $\$ 10$ million; this suggests the magnitude of the speculative profits that had been made. This episode led directly to the founding of the New York Coffee Exchange, a futures market to help regulate and stabilize the coffee market. However, speculators still attempted to manipulate both the Coffee Exchange and the market for physical coffee (Jimenez 1995: 42; Pendergrast 1999: 63-9).

Ecological effects also magnified the rise of Brazil to dominance in coffee production in the late 1800s. Coffee leaf rust, a fungus that attacks the trees, spread through Ceylon and Java, the second and third largest producers after Brazil, in the 1870s and 1880s (Samper and Fernando 2003: 424-40; Clarence-Smith 2003: 101-11). In Ceylon, planters gave up on coffee and started planting tea or rubber, while some coffee production continued on Java and the other islands of Dutch Indonesia (Clarence-Smith 2003: 110-3). Declining Asian production combined with a frost in Brazil in 1887 caused a shortage of coffee on world markets and a period of high prices through the mid 1890s (Topik 2003: 35; Samper and Fernando 2003: 451). Brazilian growers responded to the high prices by planting massive numbers of new coffee trees. The number of trees in Sao Paulo state alone increased fourfold in fourteen years (Topik 2003: 35). As the new trees began to produce, Brazilian exports began to grow rapidly in the mid $1890 \mathrm{~s}$, causing prices to fall by 50\% between 1895 and 1897 (Samper and Fernando 2003: 451). Some growers realized that overproduction was the cause, but others blamed the U.S., British, and German exporters who dominated the Brazilian export trade for manipulating prices. Growers and their political representatives floated numerous plans to rescue the coffee sector, but the Brazilian state, committed to a liberal, non-interventionist stance, refused to intervene (Topik 1987: 62-7).

Prices had recovered only slightly by 1906 , when the forecast of a record crop sent panic through the coffee regions (the actual 1906 crop turned out to be $50 \%$ higher than the previous record) (Topik 1987: 67). Brazil at this point produced about three-quarters of the world's coffee, and the world price was already low due to the persistent overproduction. A crop that large in Brazil could have caused the price to fall to near zero, ruining many large Brazilian growers. Since the federal state had declined to intervene previously, the state governments of the main coffee-producing states decided to go ahead on their own. ${ }^{14}$ They agreed to buy surplus coffee and hold it off the market to prevent the price from collapsing (Holloway 1975: 44-55; Topik 1987: 67-8). They could then gradually sell it off in succeeding years in such a way as to not undercut the price. ${ }^{15}$ However, they needed financial backing in order to buy the coffee and hold it until it could be sold. The Rothschilds, the most powerful London financial house and the main source of foreign loans for the Brazilian state, refused to get involved because they didn't think the plan would work. Herman Sielcken, head of one of the largest U.S. coffee import firms, put together the necessary financing. He ended up controlling the surplus coffee and using it to squeeze the market to make huge profits. But the intervention worked, in the sense that it did prevent the price of coffee from collapsing. This first valorization plan, as it was called in Brazil, set the pattern for future interventions by the Brazilian state. Once the Sao Paulo state

\footnotetext{
${ }^{14}$ Sao Paulo, Minas Gerais, and Rio states originally agreed to participate in the valorization, but ultimately only Sao Paulo, which stood to be the main beneficiary in any event, carried it out. Thanks to Steven Topik for this clarification.

${ }^{15}$ Because of the two-year bearing cycle, Brazilian production was virtually guaranteed to be significantly lower in 1907, so that at least some of the retained surplus could be sold relatively quickly.
} 
government had proved that intervention could work, the federal government got involved in subsequent valorizations, as did the Rothschilds, and this eventually led to the Permanent Defense of Coffee, which institutionalized state regulation of the coffee sector (Holloway 1975: 56-75; Topik 1987: 71-92).

This story illustrates the complexity of the relations between state and capitalism, and adds the dimension of core-periphery relations. Peripheral capitalism, in the person of the Brazilian planters, faced ruin in the market. They appealed to the state to subvert the operation of the market. Sao Paulo state, more directly under the control of the planters, complied, but the federal state was drawn in only reluctantly. However, neither the peripheral state nor peripheral capitalism could command the funds to finance the operation. They had to rely on capitalists in the core. Even they were hesitant to take the risk, but Sielcken and those who were willing made the super-profits; all the peripheral capitalists got from the deal was their own survival. After Sielcken demonstrated the viability of the scheme, other core capitalists were more willing to participate in future valorizations, but they almost certainly earned much lower profits. Sielcken's super-profits came not from his investment in the valorization, but from subverting the operation of the market - using his control over the valorization coffee to manipulate coffee markets in the U.S.. This manipulation forced coffee consumers to pay higher prices, and thus eventually attracted the attention of the U.S. state, which forced Sielcken to sell off the remaining valorization coffee, but not until 1913 (Holloway 1975: 69-75).

The U.S. speculators who made super-profits on coffee, represented by the Trinity Syndicate and Herman Sielcken, were the capitalist heirs of the long distance traders of the Dutch cycle. They were coffee importers, in a position to possess the most up-to-date information about production and exports from Brazil, and from other producing regions, information that the people who bought coffee from them were probably not privy to. However, they did not earn their super-profits by buying and selling coffee on the market, but by manipulating it; that is, they were operating at the level of the anti-market, as Braudel would say. Further, this manipulation required access to huge amounts of liquid capital, and its growth coincides with the beginning of the financial expansion of the British cycle, around 1870. The New York Coffee Exchange itself was a creature of the financial expansion, a new market where those who possessed huge amounts of capital could attempt to multiply it through financial dealings.

Once again during this cycle, it seems that a rapid increase in coffee consumption during the material expansion triggered not only an increase in production, but a geographic shift in its center. During the Dutch cycle, the center had shifted from Mocha to Asia (Java, Ceylon, India). During the transition to the British cycle, it shifted briefly to the Caribbean (Haiti, Jamaica, Cuba), and during the British cycle, to Latin America, particularly Brazil. In this case, there was a lag in the shift because the British were tea drinkers. Therefore the biggest increase in consumption and production came in the second half of the $19^{\text {th }}$ century, as the U.S. working class, and its coffee consumption, grew rapidly. This means that the expansion of consumption and production continued well into the period of financial expansion, whereas it had probably slowed during the financial expansion of the Dutch cycle. However, consumption stagnated after 1900 (Jimenez 1995: 42-5), and probably declined during the world depression of the 1930s. It would take the initiation of a new systemic cycle, under U.S. leadership, to revive it. 


\section{THE U.S. SYSTEMIC CYCLE ${ }^{16}$}

The fourth (U.S.) cycle began in the 1940s, with a very brief period of material expansion lasting until the early $1970 \mathrm{~s}$, and a financial expansion which may now be experiencing its terminal crisis. The organizational innovation of the U.S. cycle was a diversified and integrated national economy (as opposed to the British economy's integration with its colonies) and the internalization of transaction costs within large vertically integrated transnational corporations (TNCs) (Arrighi 1994: 269-300). The U.S. oversaw the decolonization of most of the former European colonies and their integration into the capitalist bloc during the period of material expansion, and the integrated U.S. economy became the development model for these new nations (McMichael 2004: 14-36).

Brazil's Permanent Defense of Coffee led logically to efforts to enlist major Latin American coffee producing countries into efforts to control the supply of coffee on the world market. These other Latin American countries had benefited from Brazil's unilateral efforts to support the world market price and had expanded their production during the early $1900 \mathrm{~s}$, but their growing market shares undermined the effectiveness of Brazil's efforts. However, they refused to cooperate in supply management, and during the $1930 \mathrm{~s}$, the Brazilian state was forced to destroy massive amounts of coffee that it had stockpiled to support the price, because that was cheaper than continuing to hold it. As war engulfed Europe, Latin American producers began to lose access to the European coffee market, leaving them with huge surpluses and threatening a collapse of the world market worse than had been anticipated in 1906. U.S. officials feared that the economic devastation caused by such a collapse might drive the Latin Americans, particularly Brazil, into alliances with the Axis powers. They proposed an Inter-American Coffee Agreement. Each Latin American country would be given an export quota for the U.S. market. This would control the flow of coffee into the U.S. market and head off potential cutthroat competition that could lead to a price collapse. Producing countries would receive reasonable prices for the coffee they exported, and they could then afford to store their surplus coffee and hold it off the market to support the price. This agreement would provide a model for future coffee agreements. In this case, we have an alliance of the U.S. and peripheral states acting to regulate the market, in the geopolitical interest of the U.S., but also in the long-term interests of the U.S. coffee trading and roasting companies, which would be assured of reasonably stable future supplies and prices. Coffee growers and peripheral capitalists who controlled coffee processing and export also benefited.

After World War II, as the European market again became accessible, and as coffee consumption increased after wartime controls were lifted in the U.S., world demand for coffee increased rapidly, and shortages developed. There was also a spread of coffee consumption beyond the traditional markets of the U.S. and Europe, which further increased world demand for coffee. ${ }^{17}$ One impact of the U.S. occupation of Japan was a rapid increase in coffee consumption

\footnotetext{
${ }^{16}$ Unless otherwise noted, all material in this section is drawn from Talbot (2004).

${ }^{17}$ U.S. coffee consumption actually began to decline in the 1960 s, and coffee was surpassed by soft drinks as the favorite U.S. beverage in the late 1970 s. This decline was only arrested by the specialty coffee revolution that began in the $1980 \mathrm{~s}$, although the decline leveled off in the 1990s and consumption has increased slightly in the early 2000 s. However, the decline in U.S. consumption has been more than offset by increases elsewhere.
} 
there. As living standards and per capita incomes began to rise in parts of what was now known as the Third World, middle classes began to take up the coffee habit. Latin American nonproducers such as Argentina and Chile, North African and Middle Eastern countries, and Southeast Asia all increased their shares of world coffee imports. And consumption also increased in Eastern Europe and the USSR. In many cases, coffee consumption served a particular function in the material lives of these new consumers: status symbol. It was a sign that their countries were developing and modernizing, that they now had enough disposable income to imitate the lifestyles of people in the world's richest, most powerful country. But increasingly, under the dominance of U.S. capitalism, embodied in the TNCs, lifestyles themselves became objects of consumption, that is, part of the market economy rather than material life.

The result was a new expansion and relocation of coffee production. The new area of expansion was primarily in Africa, and to a lesser extent in Asia. Two different forces drove this relocation. On the one hand, there was a rapidly growing demand for instant coffee, which could be most profitably produced with robusta, the coffee variety grown in West Africa and most Asian producing countries. ${ }^{18}$ On the other hand, the European powers and the U.S., as decolonization began to seem inevitable, were seeking to create new capitalist-oriented economic activities, or expand existing ones, to bring a measure of prosperity to the colonies and give them an economic stake in joining the "free" world. A number of African countries were already minor coffee producers, and more had the right ecological conditions for its production. With shortages of coffee developing, and demand for robusta coffee increasing, expansion of robusta coffee production in these African colonies seemed a logical choice.

The geography of the coffee commodity chain thus became much more complex than it had been in previous cycles. Where the archetypal coffee trade route during the British cycle had been Brazil to New York, there were now multiple routes, defined by (neo)colonial relations: Latin America to New York; Africa to London, Le Havre, and Hamburg; and, a bit later, Indonesia to Tokyo. The form of transactions that moved coffee along the chain remained market based as they had been during the previous cycle. While the U.S. organizational innovation involved vertically integrated TNCs, this was not characteristic of the coffee chain. The TNCs that came to dominate the coffee chain were large coffee roasting companies (who also produced instant coffee). They bought their green coffee from importers, manufactured it, and sold it to retailers. There were several reasons for the absence of vertical integration: the risks involved in coffee growing, the predominance of small coffee growers, the control exercised over coffee production and export by peripheral states, the collective action of the producing states, and the prior existence of TNC importing companies with expertise in handling coffee.

As Arrighi notes, the U.S. TNCs expanded internationally as soon as they consolidated control over the national market (Arrighi 1994: 294-95). But this happened relatively late for coffee. At the beginning of the cycle, the one transnational coffee company was Nestlé, a Swiss

${ }^{18}$ Latin America produced arabicas almost exclusively at this time, although a number of Latin American countries later began to grow robusta. East African countries in the area where coffee originated (Ethiopia, Kenya, Tanzania) produced arabica coffee. Robusta coffee was native to West and Central Africa, but was not widely commercially cultivated there until the mid-1900s. The only significant Asian coffee producers at this time were India, which produced a mix of arabica and robusta, and Indonesia, which produced mainly robusta. Java, the original European coffee outpost, began as a producer of arabica. But after the coffee plantations were devastated by the coffee leaf rust in the late $1800 \mathrm{~s}$, the Javanese switched to robusta, which was resistant to the leaf rust. 
company. The major U.S. companies did not really consolidate control over the national market until the $1970 \mathrm{~s}$, and during the $1980 \mathrm{~s}$, they began to go global, quickly gaining dominant positions in the major consuming markets of the U.S., Europe, and Japan. The market power resulting from this dominance enabled the TNC roasters to get the upper hand on the trading companies and squeeze their profit margins to the minimum. This was part of a larger process of concentration of commodities trading companies, in which the companies that survived switched from specialization in one commodity to dealing in many different ones (Chalmin 1987).

For a while, during the material expansion and stretching into the beginning of the financial expansion, the power of the TNCs was checked to some extent by the collective power of coffee exporting states. A series of International Coffee Agreements (ICAs) between all major producing states and most major consuming states regulated the world market through a system of export quotas similar to what had existed during World War II. The impetus for these agreements came from the interaction of increasing demand and the ecology of coffee production. As world demand for coffee grew rapidly after World War II, and shortages developed, world market prices spiked in 1954, stimulating a huge increase in planting of coffee, particularly in Africa and Asia. Because of the nature of coffee as a tree crop, the output of these new trees did not begin to reach the market until the late $1950 \mathrm{~s}$; thus there was over-planting. As the new coffee began to reach the market, prices fell, coffee growers turned to their states for protection, and the major Latin American coffee producers started to make plans to hold coffee off the market in order to hold the price up.

In this context, U.S. geopolitical interests dictated cooperation with the plan. The U.S. state had been shocked by the Cuban revolution, and was worried about the spread of communism through Latin America, which despite the spread of coffee production to Africa and Asia, was still the source of $70 \%$ of the world's coffee. At the same time, the European colonial powers were worried by the growing militancy of the anti-colonial movements in Africa. Under these conditions, the states of the major consuming countries were willing to enter into an agreement with peripheral states to regulate the world coffee market and create a price floor. This was seen as a disguised form of economic aid to the Third World to stop the spread of communism and keep the countries in the capitalist bloc. The series of ICAs regulated the world coffee market for most of the period 1962-1989, assuring coffee growers of reasonable prices for their coffee despite the growing dominance of TNCs over the chain. The export quotas of the ICAs also required coffee producing states to manage their coffee sectors to control exports. The ICAs were thus the culmination of a process of state intervention begun by Brazil in 1906. As was the case with the Inter-American Coffee Agreement, the geopolitical interest of the U.S. state and the long-term interests of U.S. capital (the coffee TNCs) coincided. Now, however, the peripheral states had a much more direct interest, because they regulated their domestic coffee sectors and obtained significant incomes from coffee exports, sometimes at the expense of their own coffee growers.

By 1989, many of these interests had changed. Under the pressure of the IMF/World Bank structural adjustment programs, peripheral states were seeking to expand their exports, creating a structural condition of oversupply of coffee. Coffee TNCs began to feel that the ICA was preventing them from getting the best coffee at the cheapest price. And with the Soviet bloc collapsing, the U.S. state no longer saw such strong geopolitical reasons for supporting the price of coffee. Efforts to renew the ICA failed. Under the new neoliberal orthodoxy, the capacities of most coffee producing states to manage their coffee sectors and intervene in the world coffee 
market were quickly dismantled. World market prices crashed, and since 1989, coffee prices have been at historic lows, with the exception of a brief price spike in 1994-97. ${ }^{19}$ Growers have been pressuring their states for protection from the low prices, but under current conditions, in which each country must compete for niches in the world market, the coffee producing states have been unable to recover the degree of solidarity that allowed them to cooperate in the regulation of the market during the $1960 \mathrm{~s}$ and $1970 \mathrm{~s}$. Meanwhile, the tremendous market power of the TNC roasters has allowed them to maintain or even increase the wholesale prices they charge for their roasted coffee, even as world market prices for green coffee have fallen to historic lows. This price spread is one major source of capitalist super-profits in the U.S. cycle.

The motive force behind the relocation of coffee production and the reorganization of the coffee commodity chain seems to have gradually shifted from the level of material life to the level of capitalism. During the Genoese and Dutch cycles, the uses of coffee in material life - the coffeehouse phenomenon - provided the major impetus. During the British cycle, the spread of consumption to the working classes was again the motive force, but behind this spread of consumption was the capitalist reorganization of the material lives of the mass of the population. And this prompted the working classes themselves to take a more market-oriented view of coffee consumption. During the U.S. cycle, although the spread of coffee consumption to new consumers again played an important role, the increasing demand for coffee was itself largely a creation of the advertising and demand-creation strategies of the TNCs

First, the demand for the new product, instant coffee, after the war, was largely a creation of big capital and the U.S. state. Brazilian coffee officials, seeking new ways to use the surplus coffee that was piling up in Brazil during the $1930 \mathrm{~s}$, had consulted with Nestlé technicians, who modified the spray drying machinery they used to produce powdered milk, and produced instant coffee. Instant coffee had been produced and sold before, but it had not been very good. This new process could produce large quantities of instant coffee relatively cheaply, which were superior in taste to previous products. Before Nestlé could commercialize the new process, the war intervened. But during the war, the U.S. government added instant coffee to the rations provided to its troops, simultaneously creating a huge new demand and bringing into existence a new industry to meet it. After the war, people who had gotten used to the taste and convenience of instant coffee in the armed services formed a ready-made market, and the new instant coffee industry advertised vigorously to spread the demand. Second, even the spread of the coffee habit to new consumers outside of the U.S. and Europe was driven much more by the advertising campaigns of the globalizing TNCs than had ever been the case in previous cycles. They were the ones spreading what Leslie Sklair (2002) calls the culture-ideology of consumerism: you are what you consume. Coffee became one element of a lifestyle that had to be purchased in the market, necessitating increased hours and intensity of work to enable people to purchase their desired lifestyle.

The reorganization of the coffee chain in response to these new increases in demand once again had impacts on the material lives of the people who grew the coffee. One major change

\footnotetext{
${ }^{19}$ Coffee prices began to rise slowly in about 2006, and by October 2010 had reached levels not seen since the end of the price spike in 1997. This was a result of prolonged low prices since 1997, causing many small growers to lose or abandon their land, or pull out their coffee trees and plant other crops. Under present conditions, however, this period of higher prices is likely to also be short-lived, as the rising prices will stimulate new planting, causing a new oversupply in a few years.
} 


\section{JOURNAL OF WORLD-SYSTEMS RESEARCH}

grew out of the transition from colonial production to production by independent nations, which began with growing Latin American production in the $1820 \mathrm{~s}$, and continued with the decolonization of Africa and Asia that peaked in the 1960s. This was a shift from plantation production to smallholder production. Coffee production is very labor intensive, with few economies of scale; thus small-scale producers can be just as efficient as large-scale ones. When slaves were freed, or when peasants were released from their obligations to labor on the plantations, they much preferred to grow their own coffee on their own land wherever possible. Thus by the end of the material expansion of the U.S. cycle, most of the world's coffee was being grown by small peasant producers, or by small-to-medium-sized, market-oriented farmers. Coffee production was clearly established as part of the economic life of the producers; it was grown for sale on the market. This shift had two important implications. First, swings in coffee prices had enormous implications for the economies of coffee producing countries, because so many small rural producers were involved. Second, because of this, when prices fell and small producers began to organize to demand protection from the destructive forces of the market, their states were likely to be responsive. This was the dynamic behind the ICAs, but after structural adjustment, peripheral states lost the capacity to respond, even if they wanted to.

During the financial expansion, and particularly since the end of regulation in 1989, prices have become more unstable. Coffee consumption and world demand for coffee continue to grow slowly. But production, now uncontrolled and driven by pressures from the IMF/World Bank debt regime (McMichael 2004), has generally exceeded demand. World market prices have been at historic lows, despite brief price spikes, but retail prices in the major consuming markets are high. As the TNC roasters reap enormous profits from this price gap, they cannot profitably reinvest them in the coffee trade. One symptom of the financial expansion has been the explosion of trading on the futures markets, and the introduction of new financial instruments, options on futures contracts. The TNC roasters as well as the TNC commodities traders can now reinvest some of their profits in these financial instruments. Further, they can coordinate their purchases of physical coffee and of financial instruments based on coffee, to manipulate markets and further increase their profits. But much of the increased trading volume on the futures markets has been driven by the involvement of speculators, particularly institutional speculators such as commodities funds. As the volume of futures trading has grown, the futures market prices for coffee have become the benchmarks used to set the prices used in the trade of physical coffee, the tail wagging the dog. These developments have greatly increased the price instability. TNCs, with their financial resources and global information networks, can profit from this instability, and this is the other major source of capitalist super-profits. Small coffee growers, unprotected by their states, lose. Similar trends can be seen across many other sectors of the world economy. ${ }^{20}$ The result is a growing polarization of incomes and wealth between countries and regions of the world, leading to growing political instability.

At the opening of the $21^{\text {st }}$ century, there are signs that a countermovement against the hegemony of the U.S. and its TNCs is beginning to take shape. Some of the signs are the growing

\footnotetext{
${ }^{20}$ Coffee prices were also influenced by the commodity price bubble that caused rapid increases in food prices and then equally rapid price declines during 2008. While there has been much debate over the causes of this bubble, most analysts agree that massive flows of speculative capital into commodity futures and options, and creation of even more complex financial derivatives based on commodities, played an important role.
} 
protests against the World Bank/IMF, the protests that have dogged the WTO and slowed progress of the millennium round of negotiations since Seattle in 1999, and the World Social Forum. In coffee, the most visible sign is the fair trade movement. It is no longer simply a movement of coffee growers organizing for protection against the penetration of market forces, but a movement combining coffee growers, consumers, NGOs, and small coffee trading and roasting companies. Their analysis is that the "free" trading system that has been established by governments, primarily the U.S., in alliance with the TNCs, is inherently unfair. That is, instead of focusing their attacks on market forces, they are going after the top layer of the system. And although coffee is the main fair trade commodity, the movement is expanding to other tropical products such as chocolate and bananas. These movements, as well as the growing political instability, may be part of the increasing systemic chaos that signals the coming end of the U.S. cycle, if Arrighi's analysis is correct.

\section{CONCLUSION}

I conclude by drawing out some of the implications of this analysis for Arrighi's systemic cycles and their articulation with Braudel's layers of analysis. This excursion into the lower layers of Braudel's schema suggests some additional mechanisms underlying the systemic cycles, and it also suggests some additional factors that merit consideration. Similarly, viewing Braudel's three layers in the context of Arrighi's systemic cycles also suggests new forms of connection between the layers.

Coffee consumption, and therefore the demand for coffee, seems to increase cyclically. It grows more rapidly during material expansions, and then slows or stagnates during financial expansions. This makes sense at two different levels. During material expansions, the production and trade of most commodities grows. More people are drawn into the market economy, and so more people purchase commodities, such as coffee. More generally, the material expansion is a period when commodity production is reorganized on a new and expanded basis. New classes emerge, some classes that previously existed grow in size, while still others wither or disappear. These new or growing classes are a major source of new demand. The cultural meanings of coffee to these classes in the particular historical periods play an important role in stimulating demand. During the Genoese cycle, coffee consumption was confined to small groups of elites in Europe. With the beginning of the Dutch cycle, the huge expansion in the volume and distance of trade brought an increase in the number of merchants and businessmen, as well as professionals to serve them, such as lawyers and accountants. These were precisely the classes that frequented the early European coffee houses. The British cycle brought the industrial revolution and the rise of the working class, and the expansion of coffee consumption during this period was among this class (although in the U.S. and not Britain). This generalization may not fit the U.S. cycle as well. The U.S. cycle did not really bring a new class into existence in the same way as the Dutch and British cycles. Part of the expansion in coffee consumption during the U.S. cycle resulted from the rise of professional and middle classes in new countries, outside the core of the world-economy. But another part was also created by the advertising efforts of the transnational corporations. The massive nature of this demand-creation may be a defining feature of the U.S. cycle. 


\section{JOURNAL OF WORLD-SYSTEMS RESEARCH}

During financial expansions, production and trade may continue to grow, but at a slower rate, as capital is diverted into financial deals. Coffee consumption may continue to increase, but slowly. More generally, during the course of the material expansion, the coffee habit is probably taken up by most of the members of the new class that are predisposed towards it. This means that once the material expansion runs its course, there is little room for the further spread of consumption. The major exception to this generalization is the continued expansion of coffee consumption in the U.S. well into the period of financial expansion during the British cycle. This can be explained by the different timing of U.S. industrialization, and by the fact that the U.S. was the major coffee consuming market, while the British Empire had been built partly on tea.

While consumption and production are growing during the material expansion, prices may be more stable than they are during the financial expansion. This seems to be the case for the last two cycles. During the Dutch cycle, price stability increased with the onset of the financial expansion, but this was due to the establishment of a routinized world market for coffee. Price instability and stagnating demand in the financial expansion reinforce the movement of capital away from production and trade and into financial deals and speculation, as the era's big capitalists seek to capitalize on the instability. Thus the New York coffee futures market was founded during the British financial expansion: and new speculative instruments were introduced, and trading volumes soared, during the U.S. financial expansion. Further, the Brazilians may have been able to pull off their interventions in the market in the early $20^{\text {th }}$ century in part because there was a significant volume of mobile capital seeking financial deals, which was available to finance the valorizations.

The increased coffee demand that accompanies material expansion provides the impetus for a systemwide restructuring of the coffee commodity chain. This is part of the overall reorganization of the world-economy undertaken by the new hegemonic power. This reorganization involves the relocation of the main locus of production, the reorganization of production systems, changes in the types of transactions that move coffee along the chain, and increases in the volumes of coffee flowing through the chain. The Dutch began this process with the establishment of Java as a new source of supply, and they were quickly emulated by their rivals, most notably France. However, the Dutch were content to control the trade in coffee, while the French and British pioneered the control over production by their colonists, and the use of slave labor. What had been market transactions between European traders and the Mocha coffee merchants located outside the European world-system were shifted to mercantilist transactions within an expanding system. During the British cycle, the center of coffee production moved from Asia to Latin America, particularly Brazil. Here the British interest was not in controlling the trade of coffee, but in seeking profitable investments for exported capital. These investment opportunities were found in the building of rail and port facilities in Latin America that initiated the export boom of 1850-1930. Production systems began to shift (although Brazil lagged behind) from those based on slavery to those based on small farmers. This shift was not completed until decolonization was accomplished during the U.S. cycle. The trade also shifted from a mercantilist trade, based on colonial production, to a market-based trade between nominally independent countries and firms. During the U.S. cycle, production was once again relocated, this time toward Africa and Asia, although the center remained in Latin America. This was in line with U.S. interests in overseeing decolonization in the context of the Cold War, and the competition with the Soviet bloc for the "hearts and minds" of the newly independent nations. Production systems based on small farmers were regulated by the peripheral states, until the $1990 \mathrm{~s}$, and market 
transactions predominated along the chain. Huge (although not vertically integrated) transnational firms came to control the chain through their control over the major consuming markets.

Here we see a complex interaction between the reorganization of the world-economy as a whole and the reorganization of a specific commodity chain. There is no easy one-to-one correspondence; the organization of the coffee chain enjoys a degree of relative autonomy, as Arrighi (1994: 26) puts it, from the organization of the world-economy. In several instances, the reorganization of the coffee chain seems to be in the lead, allowing rising hegemons the opportunity to test and perfect their organizational innovations. Thus, the French and British pioneered colonial production during the Dutch cycle, and the early decolonization of Latin America allowed for the development of market transactions between coffee exporters and importers during the mercantilist British cycle. It raises the question: which organizational form currently existing in the coffee commodity chain is the new organizational innovation that will propel the next hegemon to power?

In other instances, changes in the coffee chain seem to lag behind developments in the world-economy. Thus, a production system based on slavery persisted in Brazil after it had been abolished elsewhere, and colonial production persisted into the U.S. cycle, particularly in Africa. These holdovers are not too surprising. All social institutions tend to take on a life of their own and to resist change. Other discrepancies may have to do with specific interests of the hegemonic power, the legacy of previous reorganizations, or the nature of the specific commodity. British world power, for example, rested partly on tea rather than coffee, so the U.S. played a key role in reorganizing the chain during the British cycle. And because of the nature of coffee, and the legacy of previous commodity chain reorganizations, the transnational firms that came to dominate the coffee chain during the U.S. cycle were not vertically integrated. While Arrighi's periodization of capitalism is probably correct at the "top" level of the system, if we follow his research program and descend to the lower levels to look at specific commodities, we are likely to find slightly different timing across the systemic diversity of commodity chains. This is not surprising, as Arrighi's systemic cycles are general patterns that have been abstracted from the specific structural changes that occur across each of the commodity chains that comprise the world-economy.

This excursion into the lower layers of material life and the market economy therefore serves to further elaborate some of the mechanisms underlying Arrighi's systemic cycles, but also adds complexity and qualification. The interactions among Braudel's three layers are complex, and they are not determined solely by the structural logic of the top layer; however, this top layer does powerfully shape the interactions of the two lower layers. For example, I have argued that the spread of coffee consumption at the beginning of the material expansions of the most recent three cycles provided the impetus for the geographical and institutional restructuring of the chain. However, it was primarily the structural logic of the top layer that determined where production would be relocated, and how the chain would be reorganized. In addition, the periodic shortages and surpluses that send shocks through the chain are primarily market phenomena. By disrupting the flow of commodities and money along the chain, they create opportunities for subordinate players to struggle to change the structure of the commodity chain, and ultimately, the structure of the top layer of the system. At the same time, the hegemonic power retains the ability to at least shape the outcome of this struggle, if not to entirely defeat it.

The periodic shortages and surpluses also point to the role of a fourth, ecological, layer that should be added to Braudel's three-layer conceptualization. While they are phenomena of the 


\section{JOURNAL OF WORLD-SYSTEMS RESEARCH}

market, they arise out of the ecology of the coffee tree: its susceptibility to frosts, pests, and diseases; its cyclical bearing pattern, and the lag between planting and production of new coffee. In this analysis, I have only been able to sketch in a few of the connections between this layer and the other three; much more work is needed to fully integrate it into the analysis.

This analysis raises another important addition to Arrighi's theory: the concept of peripheral capitalism. I have argued that actors located in the periphery of the system can develop the same capitalist orientation as the big capitalists located in the core. They can attempt to use their market power, in alliance with their states, to subvert the operation of the market in order to earn super-profits. Because of their location in the periphery, and because their states are not as powerful as the core states, they can rarely hope to compete with the core capitalists and attain the same level of super-profits realized by them. They may be forced into alliances with core capitalists, who are able to appropriate a share of these profits, but they still probably earn higher profits than would be available to them through participation at the level of the market economy. And they may play an important role in the evolution of the systemic cycles, as did the Brazilian capitalists of the British cycle. It would be interesting to see if there were similar instances of peripheral capitalism related to other commodities during earlier systemic cycles. Peripheral capitalists, and their states, have certainly played a role, albeit subordinate, in shaping the evolution of the U.S. cycle

Turning now to the implications of this analysis for the causal connections between Braudel's three layers, one thing that is immediately apparent is the growing strength and reach of capitalism. This is seen in its ability to penetrate and reorganize the two lower layers. During the Genoese and Dutch cycles, the vast majority of the population was confined to the lowest layer of material life. Capitalism began to incorporate them into the market economy in the British cycle, a process that was nearly completed during the U.S. cycle. As this process proceeded, the layer of material life shrank correspondingly, and became increasingly shaped by the forces of capitalism, which began to influence the consumption choices that people made in the market, commodifying even the process of identity formation. Ironically, Braudel, whose analysis focuses on the period of the Genoese and Dutch cycles, sees most of the influence flowing from the top layer of capitalism down to the other two layers. But this may have been precisely the time when material life could actually exert some independent effect on the top layer of capitalism. I have argued that it was changes at the level of material life - the coffeehouse phenomenon - that opened possibilities for capitalism to reorganize the coffee commodity chain in order to earn super-profits during the first two cycles. The subsequent increases in coffee consumption during the British and especially the U.S. material expansions, in contrast, were more driven by the independent operation of capitalism as the top layer of the world-system.

However, we should not conclude that material life only shrinks and loses power over time; it can also rejuvenate and grow in new directions. Thus, revolts of enslaved people against their intolerable material lives helped to force the end of slavery, and people's general preference for growing coffee on their own small plots rather than working on plantations led to a reorganization of production on a peasant smallholder basis. I have also argued that what we now call civil society was, at least in part, an outgrowth of material life in the coffeehouses, and it has grown into a counterweight against the worst excesses of capitalism. Further, as Braudel notes, the "new" informal economy which began to grow during the financial expansion of the U.S. cycle can be seen as a sign of resistance against the incursions of market forces into material life (McMichael 2000: 217-20). 
Once again, it is important to distinguish between core and periphery. While the top layer of capitalism may dominate material life in the core, the process lags behind in the periphery. Large segments of the populations there have still not been completely incorporated into the market economy. This means that the layer of material life in the periphery may still retain some capacity to influence the unfolding of the systemic cycles at the top layer of the system. In fact, a major impetus behind the fair trade movement in coffee, and behind the movement for globalization from below more generally, is the struggle by the poor and marginalized peoples of the periphery to prevent their material lives from being colonized and reshaped by the forces of capitalism.

This study of the coffee commodity chain has focused on one small segment of the world-economy. Many more studies of this nature will be needed before we can begin to get a complete picture of the interactions among all three (or four) of Braudel's layers and the ways in which they have shaped the evolution of the systemic cycles of accumulation. The commodity chain as unit of analysis and the method of incorporated comparison seem to be useful tools for this type of investigation. The breadth of the research program that flows from Arrighi's The Long Twentieth Century is one measure of its enduring importance.

\section{REFERENCES}

Arrighi, Giovanni. 1994. The Long Twentieth Century: Money, Power, and the Origins of Our Times London: Verso.

. "Braudel, Capitalism, and the New Economic Sociology" Review 24(1): 107-23.

Braudel, Fernand. 1981. The Structures of Everyday Life: Civilization \& Capitalism $15^{\text {th }}-18^{\text {th }}$ Century, Volume 1 New York: Harper and Row. Translated from the French by S. Reynolds.

. 1982. The Wheels of Commerce: Civilization \& Capitalism 15 th $-18^{\text {th }}$ Century, Volume 2 New York: Harper and Row. Translated from the French by S. Reynolds. . 1984. The Perspective of the World: Civilization \& Capitalism $15^{\text {th }}-18^{\text {th }}$ Century, Volume 3 New York: Harper and Row. Translated from the French by S. Reynolds.

Campbell, Guryn. 2003. "The Origins and Development of Coffee Production in Réunion and Madagascar, 1711-1972" in Steven Topik and William Gervase Clarence-Smith (eds.) The Global Coffee Economy in Africa, Asia, and Latin America, 1500-1989 Cambridge: Cambridge University Press.

Chalmin, Philippe. 1987. Traders and Merchants: Panorama of International Commodity Trading Chur: Harwood Academic Publishers.

Clarence-Smith, William Gervase. 2003. "The Coffee Crisis in Asia, Africa, and the Pacific, 1870-1914" in Steven Topik and William Gervase Clarence-Smith (eds.) The Global Coffee Economy in Africa, Asia, and Latin America, 1500-1989 Cambridge: Cambridge University Press.

Dean, Warren. 1969. The Industrialization of Sao Paulo 1880-1945 Austin: University of Texas Press.

Delle, James A. 1998. An Archeology of Social Space: Analyzing Coffee Plantations in Jamaica's Blue Mountains New York: Plenum Press. 


\section{JOURNAL OF WORLD-SYSTEMS RESEARCH}

Fernando, M. R. 2003. "Coffee Cultivation in Java, 1830-1917" in Steven Topik and William Gervase Clarence-Smith (eds.) The Global Coffee Economy in Africa, Asia, and Latin America, 1500-1989 Cambridge: Cambridge University Press.

Font, Mauricio. 1990. Coffee, Contention, and Change in the Making of Modern Brazil Cambridge: Basil Blackwell.

Hattox, Ralph S. 1985. Coffee and Coffeehouses: The Origins of a Social Beverage in the Medieval Near East Seattle: University of Washington Press.

Heise, Ulla. 1987. Coffee and Coffee Houses. West Chester, PA: Schiffer Publishing Ltd. Translated from the German by Paul Roper.

Holloway, Thomas H. 1975. The Brazilian Coffee Valorization of 1906: Regional Politics and Economic Dependence Madison: The State Historical Society of Wisconsin.

Hopkins, Terrence, and Immanuel Wallerstein. 1986. "Commodity Chains in the World-Economy Prior to 1800" Review 10(1):157-70.

Jimenez, Michael F. 1995. "From Plantation to Cup': Coffee and Capitalism in the United States, 1830-1930" in William Roseberry, Lowell Gudmundson, and Mario Samper Kutschbach (eds.) Coffee, Society, and Power in Latin America Baltimore: The Johns Hopkins University Press.

McMichael, Philip. 1990. "Incorporating Comparison Within a World-Historical Perspective: An Alternative Comparative Method"'American Sociological Review 55: 385-97.

. 1992. Rethinking Comparative Analysis in a Post-Developmentalist Context" International Social Science Journal 44: 351-65.

. 2004. Development and Social Change: A Global Perspective Thousand Oaks: Pine Forge Press.

Mintz, Sidney. 1985. Sweetness and Power: The Place of Sugar in Modern History New York: Penguin Books.

Moore, Jason W. 2003. "Capitalism as World Ecology: Braudel and Marx on Environmental History" Organization and Environment 16(4): 431-58.

Pendergrast, Mark. 1999. Uncommon Grounds: The History of Coffee and How It Transformed Our World. New York: Basic Books.

Roseberry, William. 1995. "Introduction" in William Roseberry, Lowell Gudmundson, and Mario Samper Kutschbach (eds.) Coffee, Society, and Power in Latin America Baltimore: The Johns Hopkins University Press.

Samper, Mario and Radin Fernando. 2003. "Appendix: Historical Statistics of Coffee Production and Trade from 1700 to $1960 "$ in Steven Topik and William Gervase Clarence-Smith (eds.) The Global Coffee Economy in Africa, Asia, and Latin America, 1500-1989 Cambridge: Cambridge University Press.

Schivelbusch, Wolfgang. 1992. Tastes of Paradise: A Social History of Spices, Stimulants, and Intoxicants New York: Vintage Books.

Sklair, Leslie. 2002. Globalization: Capitalism and Its Alternatives. Third Edition. Oxford: Oxford University Press.

Talbot, John M. 2004. Grounds for Agreement: The Political Economy of the Coffee Commodity Chain Lanham: Rowman and Littlefield.

Tilly, Charles. 1984. Big Structures. Large Processes, Huge Comparisons. New York: Russell Sage Foundation. 
Topik, Steven. 2003. "The Integration of the World Coffee Market" in Steven Topik and William Gervase Clarence-Smith (eds.) The Global Coffee Economy in Africa, Asia, and Latin America, 1500-1989 Cambridge: Cambridge University Press.

. 1998. "Coffee" " in Topik and Allen Wells (eds.) The Second Conquest of Latin America: Coffee, Henequen, and Oil during the Export Boom, 1850-1930 Austin: University of Texas Press.

. 1987. The Political Economy of the Brazilian State, 1889-1930 Austin: University of Texas Press.

Topik, Steven and Allen Wells. 1998. "Introduction: Latin America's Response to International Markets During the Export Boom" in Topik and Wells (eds.) The Second Conquest of Latin America: Coffee, Henequen, and Oil during the Export Boom, 1850-1930 Austin: University of Texas Press.

Trouillot, Michel-Rolph. 1982. "Motion in the System: Coffee, Color, and Slavery in EighteenthCentury Saint-Domingue" Review 5(3):331-88.

Tuchscherer, Michel. 2003. "Coffee in the Red Sea Area from the Sixteenth to the Nineteenth Century" in Steven Topik and William Gervase Clarence-Smith (eds.) The Global Coffee Economy in Africa, Asia, and Latin America, 1500-1989 Cambridge: Cambridge University Press.

Tucker, Richard. 2000. "The Last Drop: The American Coffee Market and the Hill Regions of Latin America" in Tucker, Insatiable Appetite: The United States and the Ecological Degradation of the Third World Berkeley: University of California Press.

Ukers, William. 1935. All About Coffee. New York: The Tea and Coffee Trade Journal Company. Wild, Antony. 2004. Coffee: A Dark History New York: W. W. Norton.

Wrigley, Gordon. 1988. "The History of Coffee," chapter 1 in Wrigley, Coffee Essex: Longman Scientific and Technical and New York: John Wiley. 